\title{
The Making of the Luxembourger. Histories of Schooling and National Identity in the Grand Duchy
}

\author{
La formación de los luxemburgueses. \\ Historias de la educación y la identidad \\ nacional en el Gran Ducado
}

\section{La création du Luxembourgeois : Des histoires d'instruction et d'identité nationale dans le Grand Duché}

\author{
Anne Rohstock \\ University of Luxembourg, Luxembourg
}

\section{Thomas Lenz}

University of Luxembourg, Luxembourg

\section{ABSTRACT}

Since the nineteenth century the modern school not only has become an important arena for the politicians and their different national agendas but also a somewhat distorted mirror of a specific national and regional culture. As the history of the school system is deeply intertwined with the history of the nation state, school histories tend to be written within the framework of a greater national narrative. One possibility to find out what "being Luxembourgish" means is therefore to look at how school history has been written in the Grand Duchy. The authors identified one narrative which altered over time and gives a vivid impression of the changes Luxembourg underwent during its "struggle for identity" in the last 200 years.

Key words: school history; historiography of schooling; Luxembourg; schooling and national identity.

RESUMEN

Desde el siglo XIX la escuela moderna no sólo se ha convertido en un escenario importante para los políticos y sus programas nacionales diferentes, sino que también es un espejo algo 
distorsionado de una cultura específica nacional y regional. Como la historia del sistema escolar está profundamente entrelazada con la historia del Estado-nación, la historia de la escuela tiende a ser escrita en el marco de una narrativa nacional mayor. Una posibilidad para averiguar lo que significa "ser luxemburgués" es por tanto, buscar cómo la historia de la escuela ha sido escrita en el Gran Ducado. Los autores identificaron una narrativa que cambió con el tiempo y da una impresión viva de los cambios que Luxemburgo sufrió durante su "la lucha para la identidad" en los últimos 200 años.

Descriptores: historia de la escuela; la historiografía de la educación; Luxemburgo; la identidad y la educación nacional.

\section{RÉSUMÉ}

Depuis le XIX ${ }^{\mathrm{e}}$ siècle, l'école est devenue un terrain d'action non seulement pour les hommes politiques et leurs différents programmes nationaux, mais également un miroir quelque peu déformant des cultures régionales et nationales spécifiques. Etant donné que l'histoire du système scolaire est étroitement liée à l'histoire de l'Etat-Nation, on a tendance à concevoir l'histoire scolaire à l'intérieur d'un discours national supérieur. Pour savoir ce que signifie "être luxembourgeois,» on peut analyser la manière dont l'histoire de l'école a été écrite au Grand-Duché. A cette fin, les auteurs ont identifié un courant narratif qui a évolué au fil du temps et reflète précisément les changements ayant touché le Luxembourg au cours des deux siècles derniers dans sa "lutte pour l'identité."

Mots clés : I'histoire des écoles; I'historiographie de l'instruction; Le Luxembourg ; I'instruction et l'identité nationale.

\section{Contexts of historiography of schooling in Luxembourg}

$I^{N}$ N "THE SOCIAL CONTRACT" the Genevan philosopher Jean-Jacques Rousseau raises a question that political philosophers still ponder today. He says: "Before we consider the act by which a people chooses their king, it were well if we considered the act by which a people is constituted as such. For it necessarily precedes the other, and is the true foundation on which all Societies rest." (Rousseau, 1971, p. 179) Rousseau asks, in other words: What makes a people a people? How are individuals socialised into some form of national belonging? The German philosopher and educator Johann Gottlieb Fichte gave one answer to Rousseau's question in his infamous "Addresses to the German Nation" (1808): he said that the external borders of the state have to become internal borders of the individual, so that he can take this "home" anywhere he goes. Patriotism or even nationalism has to be implemented, says Fichte, into the individual either by force or - easier and better - by education.

The school is one of the places where the sense of national belonging develops, or can be developed, and it is not by chance that the modern school system arose in parallel to the modern nation-state (see Dale, Esland, Fergusson, \& MacDonald, 1981). Education researchers Ramirez and Ventresca (1992) get to the heart of the relationship among individuals, the state, and the institution of the school as follows: "Mass schooling becomes the central set of activities through which the reciprocal links between individuals and nation-states are forged" (Ramirez \& Ventresca, 1992, p. 49f.).

But not only is the history of the school and the national school system closely interwoven with the history of the modern nation-state and the formation of a "national identity" of its citizens; in addition, the historiography of schooling is also 
involved in the construction of national history. And how national identity is constructed with the help of (school-) historiography can be seen exemplarily by looking at a small nation in the heart of Europe whose sovereignty and identity was at stake for the larger part of its history: the Grand Duchy of Luxembourg. As the small country with only roughly 500,000 inhabitants ( 40 percent of them are foreigners and 98 percent are Catholics) which borders France, Germany, Belgium, and the Netherlands, the influence of these nations on Luxembourg cannot be overestimated and Luxembourg constantly tried to shape its own identity in concordance and contrast with its larger neighbours. Especially challenging was and still is the language situation in the small Grand Duchy, as French, German and Luxembourgish are offcially recognized languages and are spoken and taught in preschool and school. If one wants to believe Fichte, this should be a problematic point for the development of a concise national identity, as he believed in the importance of linguistic unity. And so the national historiography was one of the most important factors to shape the idea of a unique Luxembourgish identity. This also means that the question as to how the history of the school was (and is) written in Luxembourg should be examined from the perspective of the larger, national narrative. The case of Luxembourg can be seen as an exemplar to show how school histories can be read as ways of constructing national identities. And in the following we will show how the Luxembourgian historiography on schooling helped in constructing a Luxembourgian national identity.

Luxembourgian national consciousness developed around 1900, at a time when especially the southern part of the country was becoming industrialized and the Luxembourgian economy was highly dependent on foreign capital and labour from abroad. In this period also important political parties were founded: the Right, the Socialist Party, and the Liberal League, and their successor parties continue to characterize the politics of the country to this day. Spizzo (1995) pointed out that within a period of a few years at the beginning of the twentieth century, not only did the institutions of the nation-state develop and the foundations become firmly established for Luxembourg's upswing from an agricultural to an industrial country but also a Catholic nationalism came into being that was closely linked with the state institutions and especially with the party of the Right (which later became the Christian Social People's Party).

From the very start the question of Luxembourgian national identity was discussed along the issue of language, as Luxembourg was and is a multilingual society with French, German, and Luxembourgish as the official recognized languages of the country. Whereas the well-known publicist Batty Weber (1909) and the influential lycée teacher Nicolas Ries (1911) referred to the genuine Mischkultur [mixed culture] of Luxembourg and defined the adoption of German and French elements as a part of the national identity, which they saw as cosmopolitan and as finding expression mainly in Luxembourg's trilingualism, the members of the Letzeburger National-Union turned to a more purist understanding of the national identity of Luxembourg (Horner, 2007, pp. 368f.). Here it was especially Lucien Koenig, a $l y$ cée teacher, who attempted to define what it is that distinguishes Stackletzebuerger (or native Luxembourgers). Koenig emphasized mainly the importance of the 
Luxembourgish language (Koenig, 1911/12, p. 3). Both sides attributed special importance to the school: after all, it is the school that is supposed to impart language competencies. Whereas Ries wanted Luxembourgers to be seen as "good middle Europeans" who could mediate between German and French culture and politics, the Letzeburger National-Unio'n (and its paper, Jongletzeburg) tried to ethnicize the Luxembourgian identity: there would be no parties but only Luxembourgers. According to Horner (2007), this clash of interests between the liberal and mostly Orangist-oriented cosmopolitans and the conservative, Catholic, nationally-oriented Stackletzebuerger still exists today, and it becomes very regularly apparent in line with the issue of a Luxembourgian identity and the importance of the German, French, and Luxembourgish languages (as well as English).

The historiography of the school in Luxembourg should be understood within these political, ideological, and economic framework conditions.

The start of historiography of the school in Luxembourg in the twentieth century is marked by two works: a study by Jean Pierre Biewer (1899) on the history of the primary school and especially a commemorative publication by Van Werveke (1904) on the occasion of the $300^{\text {th }}$ anniversary of the Athenäum [Luxembourg Athenaeum] (as the high school was renamed in 1817). Van Werveke, who was a liberal historian and teacher, set the tone here for the most of the school histories that followed: he wrote a chronological success story of the school system in Luxembourg along the lines of the development of the elite school Athenäum, starting with the monastery school in the Middle Ages.

It is conspicuous that the histories of the school first appeared only in French, and then starting in the 1940s and 1950s in German, and finally in the 1970s in Luxembourgish. The percentage of English-language publications is so small as to be unimportant.

Since the 1970 s there has been a process of differentiation and professionalization of historiography in Luxembourg that has also left its mark on historiography of the school, but the teacher as historian has remained a determining influence. If we define a contemporary school history researcher as a person who in the past forty years has written at least three contributions on the school history of Luxembourg in general or on specific aspects of the school history, we find eighteen persons that fulfil this criterion as historiographers. The vast majority of school historiographers were (or are) teachers (primarily teachers at lycée classique, or general secondary school, and frequently history teachers); quite a lot of them advanced in their careers to rise to the administrative or ministerial level. Only three school historians (namely Dostert, Schmit, Trausch) were not a part of the school system. Thus the more recent history of the Luxembourgian school system is also mainly a look from the inside, and it is also one that sees the development of the school system from the viewpoint of the lycée. This lack of a view from outside the lycée might be explained by the fact, that Luxembourg's University was only founded in 2003, and before that most Luxembourgian researchers were also schoolteachers. But also in the more recent accounts, school history is told mainly as a success story that begins with an unloved Schoulmeister with his poor winter school and ends with a modern, professional 
school system. Detailed examination of particular aspects of school history are hardly found; by far greatest number of the contributions have been published as a part of commemorative publications for anniversaries of the founding of schools, or they have recapitulated chronologically the development of a single village or city school, once again with the emphasis on the lycée.

An examination of the school histories reveals that there is mainly one form of school historiography that has become influential — as can also be similarly established for Luxembourgian historiography as a whole (Péporté et al., 2010). In the following, this central narrative of the Luxembourgian historiography of the school will be worked out and more closely examined in its political, societal, and temporal contexts. Here we will show what precisely makes up the central narrative, how and why it came into being, and how and why it changed over time.

\section{Nation Building from Below: School Teachers and Variations of Luxembourgian Historiography of the School from 1880-2000}

\section{a) The Development of the National Narrative: School in the Service of the State-State in the Service of the School?}

It was at the turn of the nineteenth century that the national history of Luxembourg was invented. This has already been outlined by historiography (Péporté et al., 2010). What has been neglected so far, though, is the crucial role the historiography of schooling played in this process of nation building. Yet, it is remarkable that those who wrote history were not historians, but mainly schoolteachers. All of the 434 books published on schools in a historical perspective between 1899 and 2010 were written by pedagogues (Lenz \& Rohstock, 2010). What we can see here is a "pedagogization" of historiography; that also holds true for the Luxembourgish historiography in general. ${ }^{1}$

The fact that so many schoolteachers engaged in inventing the nation shows that the making of the Luxembourger did not remain a project of the political and cultural elites, but was on the contrary backed by ordinary people. This holds even more truth if we consider that these schoolteachers wrote their books at home after work and on weekends. To be sure, these books did not address a wide readership but served as a means of reassuring their own national identity.

How successful the teachers were in this process of nation building from below is reflected in the stability, duration, and homogeneity of the master narrative they developed. When Nicolas Van Werveke wrote his Esquisse de l'histoire de l'enseignement et de l'instruction dans le Luxembourg in 1909, the teacher laid the foundations for a tradition of Luxembourgian historiography of the school that would survive far into the second half of the twentieth century (see Kirsch, 1987; Thein, 1963). Van Werveke (1904) placed the birth of Luxembourg's national school system in the High Middle Ages - at a time, therefore, that preceded the rise of the nation-state of Luxembourg in the nineteenth century by about 800 years. In this way van Werveke established a school history narrative that, as an "invented tradition" to use Hobsbawm and 
Ranger's (1992) term, fulfilled an unambiguous political mission: stabilization and legitimatization of the still young state of Luxembourg.

With this deliberate nationalization of the Luxembourgian school system since the Middle Ages, van Werveke was taking up already established historical narratives that served to legitimize the modern nation-state. In publications in the late nineteenth and early twentieth century, a number of history teachers, from Arthur Herchen to Nicolas Margue to Joseph Meyers, had attempted to trace Luxembourg's original "autonomy" back to the Middle Ages — an "independence" that in their opinion had been disrupted by about 350 years of what they called foreign domination and that was only re-established through the Congress of Vienna in 1815.

In fact, however, the Grand Duchy of Luxembourg as we know it today was not granted full political autonomy until 1839. From 1815 to 1830 the Grand Duchy belonged to the Netherlands, and thus it was basically under "foreign domination" far longer than the Luxembourgian historiography suggests. But there is a concrete reason for the fact that the Netherlands period was apparently not seen by the Luxembourgers as a further period of foreign domination. The Dutch had cleverly filled key posts in the Grand Duchy with persons loyal to the House of Orange dynasty - and this is also mainly true for the historical accounts. The personnel at the most important production site of historical interpretations, the history section of the Grand Ducal Institute, the national academy of Luxembourg, had clearly liberal/Orangist leanings and produced a very positive picture of the era under the Netherlands. The years between 1815 and 1830 were consequently viewed as the founding date of the Luxembourgian nation-state, and this narrative moulds Luxembourgian historiography up to today (Péporté et al., 2010).

This affirmative attitude towards the period under the rule of the Netherlands also appears in nearly all publications on school history. It is all the more conspicuous, as the Belgian rule of Luxembourg that followed (1830 to 1839) was judged almost without exception as negative. Whereas King William I of the Netherlands was said to have worked "tirelessly" for the education of his subjects, as a Luxembourgian primary school reader of 1884 tells us (Vaterländisches Lesebuch, 1884), other publications determined that there was "total" neglect of the school system under the aegis of Belgium (Kass, 1977, p. 69). This narrative had mainly a legitimizing function. For at the same time that the Belgian rule was deemed negative, the achievements of Luxembourg's first school law of 1843, which put a stop to the alleged "anarchy" in the school system, could be put all the more in a positive light (Gelhausen, 1981, p. 7). This narrative subsequently took on a life of its own, as shown by some publications on school history that even attempted to draw parallels between the period of Belgian rule and the subjugation of the country by the National Socialists from 1940 to 1944 (see, for an example, Bosseler, 1970).

But the national master narrative was produced not only by the liberal Orangists. As school and school history became more and more important for the rise and maintenance of the modern nation-state, interest in securing school-specific spheres of power and influence also grew on the part of other political and social groups, particularly the Catholic Church. In its contributions on school history, the Catholic 
Church tried in a targeted fashion to historically legitimize its "natural" authority, as it were, in the Luxembourgian school system. For example, a publication stated in 1899, "Tout ce qui s'est fait pour l'enseignement de notre pays revient exclusivement au Clergé" (Grob, 1899, p. 517). The fact that the clergy in Luxembourg attempted to gain sovereignty of interpretation on the national school history at precisely the same time that in neighbouring Germany the Kulturkampf (conflict between the Prussian state and the Roman Catholic Church from 1871 to 1887) and anti-Jesuit legislation reached a high point, while at the same time secular developments took hold in the bordering country of France, shows the great extent to which the time of birth of the nation-state of Luxembourg was already influenced by international developments and local and national reactions. Also noticeable are efforts by various churchmen towards the end of the nineteenth century and at the beginning of the twentieth century to establish connections between the Jesuit Order, founded in 1534 and restored in Rome in 1814, and Luxembourgian schoolmasters and teachers (see, for examples, Blum \& Mueller, 1896; Vannerus, 1899). By demonstrating historical authority of the Catholic Church in the Luxembourgian school system, they hoped to be able to also safeguard the present and future influence of Catholicism on the field of education (see, for example, Margue, 1966).

In the Catholic historiography in this connection the reservations especially expressed about measures taken by the French (1795-1815) and Belgian rulers (18301839 ) in the school did not grow out of an allegedly typical Luxembourgian antirevolutionary stance but rather out of a specific Catholic understanding of the school and the state (Dostert, 1994). This is especially clear in some Luxembourgian publications in their judgment of what were called the écoles centrales. The Luxembourgian school historiography had an unequivocally negative attitude towards these educational institutions, which were an important school-specific new phenomenon of the French period and were established in the Grand Duchy between 1795 and 1815 . The reason for the negative judgment was the allegedly overly strong scientific orientation of these institutions that was said to have overtaxed both teachers and pupils completely (Sprunck, 1964a; Sprunck, 1964b; Sprunck, 1967). Possibly the écoles centrales met with so little approval by the school histories of Catholic provenance above all because the educational institutions were dedicated to the ideals of the Enlightenment and with their strong emphases on the natural sciences supposedly threatened to undermine the Catholic worldview.

But why did many Catholic authors also reject measures instituted in the area of schooling by the Belgian rulers? After all, the Belgian rulers in Luxembourg were clearly Catholic in orientation. One possible reason is that between 1830 and 1839 the Belgian state noticeably withdrew from the school system and thus no longer explicitly protected the church educational institutions, leaving them to their own resources. During the period of Belgian rule, every citizen had the potential right to open a school. That was not what the Catholic clergy had in mind, who for some time had been seeking from the state a lawfully guaranteed sphere of autonomy in the area of schooling (Linster, 1968). ${ }^{2}$ In the eyes of the church, the Catholic influence on the education system in Luxembourg could be realized only in cooperation 
with the nation-state. It is due mainly to this fact that the Catholic historiography of the school for a long time supported the nation-state-based narrative of the liberal Orangists.

\section{b) First Variation of the National Master Narrative: Internationalization}

It took somewhat longer than half a century before a first variation of the very powerful national narrative began to become apparent in the historiography of the school. Only in the 1960s do we find timid approaches towards reframing the master narrative. They aimed mainly at internationalizing Luxembourgian history. The opening of the country towards Europe, which found expression, for example, in the founding of the European Coal and Steel Community in 1952 and the signing of the Treaties of Rome in 1957, resulted in this way in a firmer embedding of the Grand Duchy in international connections (Trausch, 1987; Trausch, 1999). But there was no rejection or deliberate break with the handed-down national narrative connected with this. On the contrary, the internationalized reframing of Luxembourgian history in general and school history in particular stood to a certain extent in the same national tradition and again was aimed at legitimizing the Luxembourgian state. In this way, the Europeanization of the history of Luxembourg fit quite smoothly into the previous national narrative. In a historical respect, with this the Grand Duchy realized in a pure form, so to speak, a demand made by the French head of state Charles de Gaulle: in 1962 the "General" had called for a "Europe of Fatherlands" (Conze, 1995).

But how exactly did this internationalization of the national narrative come about, and how is it linked to changes in the historiography of the school? Like its neighbours to the west and east, in the late 1950s and early 1960s Luxembourg went through developments that contemporary historical research has labelled democratization, liberalization, and Westernization and that very generally appeared to initiate the way towards a golden age of the Trente Glorieuses [The Glorious Thirty] years from 1945-1975 (Hobsbawm, 1995; Fourastié, 1979). Especially the changing global framework (Cold War and the North-South conflict) led to stronger international pressures of competition and caused contemporaries to see further than the end of their (national) noses. Discussions in the 1960s on modernization, progress, and technology were basically the expression of this expanded field of vision, and they explain in an illustrative way the will of the contemporaries not to miss out on the international developments.

The Luxembourgian school system was ascribed great importance for the dawning new age; here, too, the Grand Duchy did not differ from other Western European countries. The schools were to be made fit "for the future," "for tomorrow," "for a modern spirit" ("Schulen für die Zukunft," 1961, p. 1; "Schulen für morgen," 1962, p. 3; Friedrich, 1969, p. 23). At the same time, educational institutions were opened to an éducation moderne, young people were to catch up with the demands of the modern world, and teaching was to be adapted to the requirements of modern times ("L'éducation moderne," 1961, p. 3; “Abitur-Rede," 1961; Raths, 1964, p. 229). The number of contemporary publications in politics and society on these topics 
(see, for example, Stoffel, 1954; "Etudes a l'étranger," 1960; "Zu viele Begabungen," 1963; "Die Begabungspflege," 1965) shows that these education-specific modernization desires were very much connected with demands for an internationalization and economization of the Luxembourgian school system.

The atmosphere of departure also affected the Luxembourgian historiography of the school. In parallel to the general opening of the country towards Europe, starting in the late 1950s an increasing number of publications attempted to embed the historical developments in education more firmly in the international (economic) context (see, for example, Linster, 1968; Beffort, 1967; Gretsch, 1978; Trausch, 1964). The new modernization paradigm as a powerful expression of these internationalization efforts shaped above all school history accounts of the time after the turn of the twentieth century (Friedrich, 1969). Since then, as was stated in a publication in the year 1970, the Luxembourgian schools, under the direction of "teaching personnel trained in an exemplary manner," were "flying at high altitudes;" this "competent" modernization of the school system had brought the schools to a "noteworthy high point" (Bosseler, 1970, p. 133).

Stronger than before, there was a welcoming of those developments in the history of the school in Luxembourg supposedly fostered by secular and anticlerical tendencies in the school system of the Grand Duchy (see, for example, Diederich, 1973; Moia, 1967). For instance, the school historiography dominated by teachers celebrated the Luxembourg school law of 1912 as libération de l'instituteur from the claws of the clergy (Kirsch, 1987).

The secularization of the history in service of international developments put pressure to act on the Catholic Church, which had previously supplied the interpretations for school history narratives. Unwilling to give up the rank and status it had claimed for centuries, the Catholic Church subsequently carried out the same opening in Luxembourg that had gripped the entire institution after the practically symbolic death of the ultramontanist Pope Pius XII and the Second Vatican Council. Numerous articles in newspapers and journals show that at the beginning of the 1960s the Luxembourger Catholics tried to pursue new and international courses especially in the education sector. The educational works of John Dewey and William Heard Kilpatrick in particular were received attentively and interpreted in a Catholic way. As was written in 1961 ("Für und wider die amerikanische Pädagogik," 1961, p. 9), because "the educational sphere" was "caught up in the waves of influence coming from the United States to the whole world," it was time also in Luxembourg to become open to a "truly progressive, personal education in a Christian democratic spirit." In 1964 in an article in the monthly journal of the Priests of the Sacred Heart of Jesus, Steinmetz stated the school no longer had the right to "establish itself as an encapsulated island and to deny the real life (outside) admittance" (Steinmetz, 1964, p. 239). On the contrary, as another demand from Catholic circles put it (Raths, 1964), the school was now to "stand in the middle of life" (p. 229).

Just how strongly this Catholic Pragmatist reorientation in the 1960s influenced the Christian-oriented school history in Luxembourg is clearly evident, for one, in the cautious re-evaluation of the écoles centrales established under French rule. Very much 
in contrast to the centuries before, in the 1960s these institutions were even said to have had positive effects on the school system in Luxembourg. After all, the focus on the natural sciences during the Régime français had resulted in considerable improvements in the teaching of physics, for example. It is certainly no coincidence that precisely in the "technical/scientific age," as contemporaries in the East and West called it, the natural science and technical aspects of instruction at the écoles centrales of the seventeenth century were pointed out with praise (see, for example, Trausch, 1964).

For another, Church-oriented authors in the 1960s made a very deliberate attempt to draw a connection between the Luxembourg school reforms of the decade, which were initiated primarily by politicians, and an allegedly considerably older educational reform tradition of Catholicism. In any case, a number of authors viewed the tendencies in the reform discussions towards internationalization of the school system and towards practically relevant training of teachers and pupils as being in line with the "modern" school reform attempts by Pope Leo XIII in the late nineteenth century (Pfeiffer, 1968; Hierzig, 1977).

In this way, the Catholic Church itself became an agent of the internationalization of school historiography. The Church was very cleverly able to adapt to the gradual shift in emphasis within the school history master narrative. By reinventing itself (so to speak) in terms of school history, it was not only able to assert its power as interpreter of school history but moreover was also able to itself make a considerable contribution to the international re-interpretation and variation of the national school historiography master narrative.

\section{c) Second Variation of the National Master Narrative: Regionalization and Multiculturalization}

An almost hectic search for identity became apparent in the Grand Duchy starting in the late 1970s and early 1980s that very strongly returned to the past, to values and native traditions that had supposedly been broken. This "return to history" can be demonstrated in the school historiography not only quantitatively. ${ }^{3}$ Also in content, accounts dominated that were explicitly devoted to investigation of the teaching of history in Luxembourg in its historical genesis (see, for example, Muller, 1989; Thill, 1989; Thill, 1994). In a way, this return to history was equivalent to a return to national history: namely, the publications of the 1980s and 1990s repeatedly referred to the time of the 1960s, when there was supposedly no sense of history, and when mainly national history, which had in fact been removed from the syllabus in 1968, hit rock bottom. Typically, these publications did not rate the break with tradition of the National Socialist domination as the lowest point in the teaching of history; after all, after the Second World War Luxembourg had been able to smoothly resume "ses traditions d'avant guerre" and had already returned to normality by $1945 / 1946$. The actual backward movement, or "recul brutal," was identified as the reforms of 1968. The unanimous opinion was that only a new history textbook published in 1971 had returned national history to its rightful place (Muller, 1989).

However, this re-nationalization of Luxembourg's past school history in the 1980s and 1990s was not connected with a complete return to the original national master 
narrative. For one, namely, the national past of Luxembourg in school history accounts was frequently connected with the future. For instance, a 1987 publication dealing with the school law of 1912 emphasized the importance of "de se rappeler les bons examples du passé pour puiser de nouvelles forces” (Kirsch, 1987, p. 8). For another, the historiography of the school shows that whereas the search for identity in the new times still did not break with the national master narrative, it definitely emphasized other things. The formerly national master narrative was now re-interpreted in the direction of a regionalization that placed the Luxembourgian school and education system much more strongly than before in regional contexts and connections (Wittenbrock, Michaux, \& Dostert, 1994). But like the internationalization of school history as the first variation of the national master narrative, the function of also the second variation of the original school historiography melody was to legitimize Luxemburg as an independent nation-state - this time in the context of a call for a "Europe of Regions" in 1985 (Ruge, 2003).

Closely connected with this regionalization of the nation-state narrative was a turn to language, which in the 1980s became the identification object of not only Luxembourg but also many European regions. ${ }^{4}$ In Luxembourg this "turn to language" is reflected in the law of 1984 concerning the use of languages, which raised Luxembourgish to the status of the national language (Péporté et al., 2010). Two developments show that this was not connected only with a conservative and protective return to the native country and traditions. First, in parallel to Luxembourgish being made the national language, for the first time in school history a previously unnoticed group became the focus of public attention: namely, immigrants (Caldognetto, 1999; Temps de migrations, 1997; Centre de Documentation sur les Migrations Humaines, 1998; Hoegener, 1986). For immigrants, the language question was not an issue of national vitality, but it was nonetheless very important for their social and economic integration. Second, in this context Luxembourg's multilingualism became viewed as an allegedly specifically national characteristic. In 1989, for instance, the historian Michel Schmit judged the attempt of the Dutch rulers to permit only French as the language used in the school system to have been a "décision radicale," as it broke with the since 1817 "longue tradition d'enseignement bilingue" in Luxemburg (Schmit, 1989). This invention of the bilingualism and multilingualism of the Luxembourgers, which can be found also in other publications (see, for example, Diedrich, 1989), was for its part the expression of a generally conceded and supposedly historically evidenced cultural hybridity of the Luxembourgers (Péporté et al., 2010).

This hybridization of a national conception of identity probably the most evidently expresses the enormous ability of the national (school history) master narrative to change. Its more or less trouble-free adaptation to changed political, social, and international conditions over a period of about 150 years explains the tremendous persistence of the narrative. Owing to its constant re-invention by the contemporaries in the 1990s, it was naturally not the same as it had been at the end of the nineteenth century. Nevertheless, practically all authors of school histories are positioned clearly in the tradition of the original narrative. In the entire period examined, in 
Luxembourg it never came to the kind of break with national narratives that occurred in the 1960s in nearly all Western European countries (Raphael, 1996). This means that not only do we find in the Grand Duchy almost none of the political and ideological frictions that are so typical of the history of educational systems, but also even the most conflict-fraught school-specific argument between the Catholic conservatives and the liberals dating back to the year 1912 was afterwards placed in service of one and the same aim: legitimation of the Luxembourgian nation-state.

\section{Concluding Remarks}

The continuous reinvention and adjustment of the school narrative at the same time reflects alterations in the Luxembourgian concepts of identity. These different concepts did not go as well with one another as the historiography of schooling suggests at a first glance. Whereas in the late nineteenth century Catholic conservatives and liberal Orangists had been opposing each other, the dividing line nowadays runs between local- and traditional-orientated, nationalist Luxembourgers on the one hand and cosmopolitical, multilingual European citizens on the other hand (Horner, 2007). The fact that this conflict tends to be harmonized by the historiography of schooling hints at the fundamental problems underlying the project of nation building. For instance, multilingualism as the key element of the Luxembourgish identity was contested for a long time: as we know today, German-speaking school children and their parents opposed the introduction of French as a teaching language (Voss, forthcoming). In the final analysis, the nation's identity in the past 150 years was much more fragile than most Luxembourgers today presume (and the school historiography suggested). It is probably this small nation's longing for consensus that best expresses the Luxembourgian struggle for identity (Trausch, 2009). And it is possibly in this struggle for national sovereignty, international uniqueness, and regional/local singularity where one can find a cultural idiosyncrasy that withstands international tendencies to harmonize the educational globe.

\section{Notes}

1. As Péporté et al. (2010) show, teachers in general also mainly wrote national history.

2. That is also suggested by the Catholic conservative interpretation of the conflict over the Luxembourgian school law of 1912 or the interpretation of the Constitution of Luxembourg.

3. More than three-quarters of all books and articles written on school history in Luxembourg have been published in the 1980s.

4. Péporté et al. (2010) speak of a turn of the European regions to minority languages and point out legal reforms in 1976 in Belgium, in 1975 and 1976 in France, in 1978 in Spain, and in the 1970s in Switzerland. 


\section{References}

Abitur-Rede. Ist unsere Jugend, wenn sie die Schule verlässt, gerüstet für die Anforderungen der modernen Welt? Hier die Antwort einer Abiturientin. (1961, Nr. 28). d'Letzeburger Land, 7.

Beffort, A. (1967). Le système scolaire au Grand-Duché de Luxembourg tributaire de l'économie nationale. Namur, Belgium: Institut international pour les problèmes humains du travail.

Biwer, J. P. (1899). Ėtude sur le développement de l'instruction primaire publique dans le Grand-Duché de Luxembourg. Luxembourg: V. Bück, L. Bück.

Die Begabungspflege. (1965, Nr. 32). d'Letzeburger Land, 4.

Blum, M., \& Mueller, M. (1896). Das Collegium Germanicum zu Rom und dessen Zöglinge aus dem Luxemburger Lande. Hemécht. Zeitschrift für Luxemburger Geschichte, 12-16, 123-127, 154-157, 204-210, 242-246, 272-275, 303-306, 329-332, 372-374, 397-400, 426-427.

Blum, M., \& Mueller, M. (1897). Das Collegium Germanicum zu Rom und dessen Zöglinge aus dem Luxemburger Lande. Hemécht. Zeitschrift für Luxemburger Geschichte, 37-39, 91-94, 115-119, 168-173, 222-227, 323-326, 383-388, 403-410, 477-495, 566-574, 632-636, 681-684.

Blum, M., \& Mueller, M. (1898). Das Collegium Germanicum zu Rom und dessen Zöglinge aus dem Luxemburger Lande. Hemécht. Zeitschrift für Luxemburger Geschichte, 15-18, 110-121, 186-191, 226-233, 285-288, 329-331, 395-400, 447-452.

Blum, M., \& Mueller, M. (1899). Das Collegium Germanicum zu Rom und dessen Zöglinge aus dem Luxemburger Lande. Hemécht. Zeitschrift für Luxemburger Geschichte, 5-12, 69-71.

Bosseler, N. (1970). Das Volksschulwesen in seiner allgemeinen Entwicklung und in Hagen im Speziellen. In 100e anniversaire des sapeurs-pompiers de Hagen, 1870-1970 (126-144). Esch-sur-Alzette, Luxembourg: F. Philippi.

Caldognetto, M. L. (1999). Il y a cent ans, on apprenait l'italien au Grand-Duché: Cours italiens, cours d'italien, soucis éducatifs à Esch-sur-Alzette entre 1900 et 1914. In A. Reuter (Ed.), Luxembourg - Italie. Hommage au père Benito Gallo. Dudelange, Luxembourg: Centre de Documentation sur les Migrations Humaines.

Centre de Documentation sur les Migrations Humaines. (1998). 50 Joer Schoul Italien: L'histoire d'un quartier à travers son école et la vie diune institutrice. Dudelange, Luxembourg: Centre de Documentation sur les Migrations Humaines.

Christophory, J. (2003). Un demi-siècle d'histoire nationale et européenne - et une biographie. Rencontres fortuites ou mystérieuses complicités athéniennes? In Athénée de Luxembourg, 400 Joer Kolléisch: Vol. IV. Hommage à l'Athénée (31-37). Luxembourg: Éd. Saint-Paul.

Conze, E. (1995). Die gaullistische Herausforderung: Die deutsch-französischen Beziehungen in der amerikanischen Europapolitik 1958-1963. Munich, Germany: Oldenbourg Verlag.

Dale, R., Esland, G., Fergusson, R., \& MacDonald, M. (Eds.) (1981). Schooling and the national interest. Barcombe, England: Falmer Press.

Diederich, V. (1973). Notre loi scolaire aperçu publié à l'occasion du soixantenaire de la loi du 10 aồt 1912 concernant l'organisation de l'enseignement primaire (Association des instituteurs réunis, Ed.). Luxembourg: V. Bück.

Diederich, V. (1989). Notre enseignement primaire - essai historique. In M. Gerges (Ed.), Mémorial 1989. La société luxembourgeoise de 1839 à 1989 (337-368). Schwebsange, Luxembourg: Éditpress.

Doppeldeutiges Jubiläum. (1981, April 24, Nr. 17). d'Letzeburger Land, 7.

Dostert, P. (1994). Der Geschichtsunterricht in Luxemburg 1918-1944. In R. Wittenbrock, G. Michaux, \& P. Dostert (Eds.), Schule und Identitätsbildung in der Region Saar-LorLux. Einseignement scolaire et formation d'identités collectives dans l'espace Sar-Lor-Lux (25-44). Saarbrücken, Germany: Ottweiler. 
Dühr, J. (1884). Vaterländisches Lesebuch für die Luxemburger Volksschule. Luxembourg: V. Bück.

L'éducation moderne. (1961, Nr. 42). d'Letzeburger Land, 3.

Etudes a l'étranger (1960, Nr. 4). d'Letzeburger Land, 12.

Fourastié, J. (1979). Les Trente Glorieuses ou la Révolution Invisible de 1946 à 1975. Paris, France: Fayard.

Friedrich, E. (1969). Den Echternacher Kollisch. Moderner Geist in alten Mauern. Revue, 24(15), 23-30.

Für und wider die amerikanische Pädagogik. (1961, Nr. 40). d'Letzeburger Land, 9.

Gallo, B. (1987). Les Italiens au Grand-Duché de Luxembourg. Un siècle d'histoire et de chroniques sur l'immigration italienne. Luxembourg: Impr. Saint-Paul.

Gelhausen, H. (1981). Ein Jahrhundert Schulpflicht. d'Letzeburger Land, 7.

Gretsch, L. (1978). 25 Jahre Europaschule in Luxemburg. Luxemburger Wort, 6.

Grob, J.-W. (1897). Zur Kulturgeschichte des Luxemburger Landes. Zwanglose Skizzen. Heft 1: Die Schule. Luxemburg: Impr. Saint-Paul.

Hierzig, F. (1977). Vor hundert Jahren bereits Fortbildung für Lehrer. École et vie, 95-96.

Hoegener, R. (1986). 75 ans d'école du Brill. Itinéraire et monument de l'immigration. In 75 Joer Brillschoul. Esch-sur-Alzette, Luxembourg: Administration communale.

Hobsbawm, E., \& Ranger, T. (1992). The invention of tradition. Cambridge, UK: Cambridge University Press.

Hobsbawm, E. (1995). Das Zeitalter der Extreme. Weltgeschichte des 20. Jahrhunderts, München, Germany: dtv.

Horner, K. (2007). Language and Luxembourgish national identity: ideologies of hybridity and purity in the past and present. In S. Elspaß et al. (Eds.), Germanic Language Histories from Below (1700-2000) (363-378). Berlin, Germany: de Gruyter.

Kass, J. (1977). Vom Schulwesen in früherer Zeit. In 100e anniversaire de la Chorale Ste Cécile Brandenbourg 1877-1977 (67-75). Brandebourg, Luxembourg: Impr. Print-service.

Kirsch, E. (1987). La loi Braun de 1912. La libération de l'instituteur. Recueil de mémoires publiées à l'occasion du 75e anniversaire de la loi scolaire de 1912. Luxembourg: éd. FGIL.

Linster, G. (1968). La question scolaire. Ses racines dans notre histoire politique In Almanach culturel 1968 (57-86). Esch-sur-Alzette, Luxembourg: Impr. Coopérative luxembourgeoise.

Margue, P. (1966). Profils de Fondatrices. Hémecht. Zeitschrift für Luxemburger Geschichte, $163-170$.

Moia, N. (1967). Pour la laïcité dans nos écoles. Thèse pédagogique. Luxembourg.

Muller, G. (1989). L'histoire dans l'enseignement secondaire (1939-1970). Ré-création. Magazine culturel de l'APESS, 238-244.

Newcomer, J. (1995). The Grand Duchy of Luxembourg. The Evolution of Nationhood. Luxembourg: Le Bon Livre.

Péporté, P., Kmec, S., Majerus, B., \& Margue, M. (2010). Inventing Luxembourg: Representations of the past, space and language from the nineteenth to the twenty-first century. Leiden/Boston: Brill.

Pfeiffer, A. (1968). Das Priesterseminar in Luxemburg als philosophische und theologische Fakultät 1898-1907. Hémecht. Zeitschrift für Luxemburger Geschichte, 57-70.

Ramirez, F., \& Ventresca, M. (1992). Building the Institution of Mass Schooling: Isomorphism in the Modern World. In: B. Fuller and R. Rubinson (Eds.), The Political Construction of Education. The state, school expansion and economic changes (47-60). New York, NY: Praeger Press.

Rapahel, L. (2003). Geschichtswissenschaft im Zeitalter der Extreme. Theorien, Methoden, Tendenzen von 1900 bis zur Gegenwart. München, Germany: Beck.

Raths, A. (1964). Historisches über die Entwicklung unseres Primärschulwesens. Heimat und Mission, 225-229. 
Ries, N. (1911). Essai d’une psychologie du peuple luxembourgeois, Diekirch, Luxembourg: P. Schroell.

Rousseau, J.-J. (1979). The Social Contract. In: E. Barker (Ed.), Social Contract: Essays by Locke, Hume, Rousseau (170-182). New York, NY: Oxford University Press.

Ruge, U. (2003). Die Erfindung des "Europa der Regionen“. Kritische Ideengeschichte eines konservativen Konzepts. Frankfurt am Main, Germany: Campus.

Schmit, M. (1989). Aperçu sur un siècle et demi d'enseignement supérieur et moyen. In M. Gerges (Ed.), Mémorial 1989. La société luxembourgeoise de 1839 à 1989 (395-412). Luxembourg: Éditpress.

Schulen für die Zukunft (1961, Nr. 27). d'Letzeburger Land, 1, 2.

Schulen für morgen (1962, Nr. 38). d'Letzeburger Land, 3.

Spizzo, D. (1995). La nation luxembourgeoise: genèse et structure d'une identité. Paris, France: CIEMI: L'Harmattan.

Sprunck, A. (1964a). L'école secondaire de Luxembourg (1802-1808). Hémecht. Zeitschrift für Luxemburger Geschichte, 275-287.

Sprunck, A. (1964b). L'école centrale du Département des Fôrets. Hémecht. Zeitschrift für Luxemburger Geschichte, 13-36.

Sprunck, A. (1967). Les écoles primaries de Ville de Luxembourg sous le Régime Français. Hémecht. Zeitschrift für Luxemburger Geschichte, 457-476.

Steinmetz, A. (1964). Neuer Wind in neue Schulen. Heimat und Mission, 235-241.

Stoffel, M. (1954). Le Statut national de nos Etudiants et la Communauté Européenne. d'Letzeburger Land, 2, 11.

Temps de migrations - tempi di migrazioni (1997). Projet Comenius 1996-97. Lycée de garçons Esch/Alzette - Liceo Brocchi Bassano. Luxembourg: Rapidpress.

Thein, J. (1963). Beiträge zur Geschichte des Volksschulwesens in Luxemburg mit besonderer Berücksichtigung von 350 Jahren Schulwesen in Wiltz. Diekirch, Luxembourg: Le Nord.

Thill, A. (1989). L'enseignement de l'histoire dans les années 70 et 80 . Une difficile recherche d'identité. Ré-création. Magazine culturel de l'APESS, 245-250.

Thill, A. (1994). L'enseignement de l'histoire au Luxembourg depuis 1945. In Schule und Identitätsbildung in der Region Saar-Lor-Lux = Enseignement scolaire et formation d'identités collectives dans l'espace Sar-Lor-Lux (119-133). Saarbrücken, Germany: Ottweiler.

Trausch, G. (1964). Un règlement scolaire en 1799. Hémecht. Zeitschrift für Luxemburger Geschichte, 214-216, 327-332.

Trausch, G. (1981). L'immigration italienne au Luxembourg des origines (1890) à la grande crise de 1929. Hémecht. Zeitschrift für Luxemburger Geschichte, 443-471.

Trausch, G. (1987). Le Luxembourg face aux traités de Rome. La stratégie d'un petit pays. In Il rilancio dell'Europa e i trattati di Roma $=$ La relance européenne et les traités de Rome $=$ The relaunching of Europe and the treaties of Rome (423-459). Bruxelles, Belgium: É. Bruylant.

Trausch, G. (1999). Conscience de l'identité européenne après 1945. In Réflexions sur l'identité européenne. Bruxelles, Belgium: Commission européenne.

Trausch, G. (2009). Le Luxembourg, une société de consensus. Handbuch der sozialen und erzieherischen Arbeit in Luxembourg = Manuel de l'intervention sociale et éducative au Grand-Duché de Luxembourg. Luxembourg.

Vannerus, J. (1899). Notes biographique sur des Jésuites nés dans l'ancien Luxembourg ou ayant fait partie des colleges de Luxembourg et de Marche (1627-1765). Hémecht. Zeitschrift für Luxemburger Geschichte, 349-356, 398-405, 455-467.

Van Werveke, N. (1904). Esquisse de l'histoire de l'enseignement et de l'instruction dans le Luxembourg. Luxembourg: J. Beffort.

Voss, P. (forthcoming). The bureaucratic turning point. The improvement of primary schooling in mid-19th century Luxembourg. 
Wittenbrock, R., Michaux, G., \& Dostert, P. (Eds.) (1994). Schule und Identitätsbildung in der Region Saar-Lor-Lux Enseignement scolaire et formation d'identités collectives dans l'espace Sar-Lor-Lux. Saarbrücken, Germany: Ottweiler.

$\mathrm{Zu}$ viele Begabungen werden verschwendet (1963, Nr. 7). d'Letzeburger Land, 8. 